\title{
Breast cancer screening in Primary Health Care in Brazil: a systematic review
}

\author{
Rastreamento do câncer de mama na Atenção Primária à Saúde no Brasil: revisão sistemática \\ Cribado del cáncer de mama en la Atención Primaria de Salud en Brasil: una revisión sistemática
}

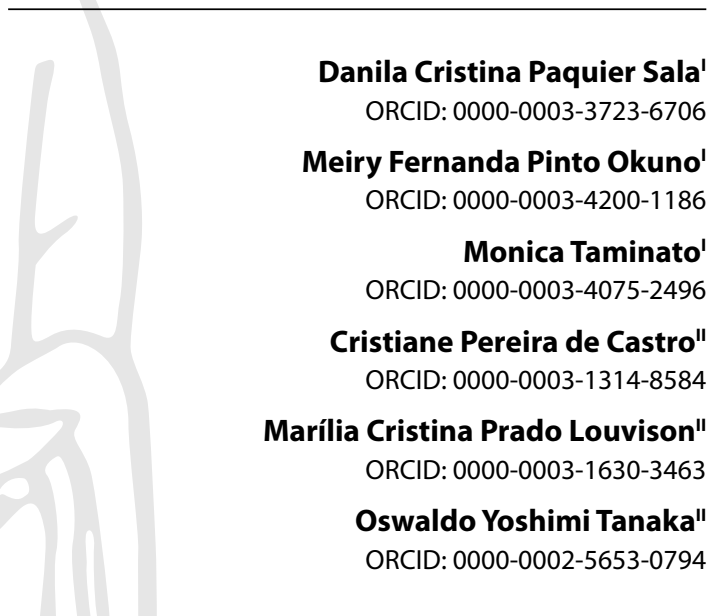

'Universidade Federal de São Paulo. São Paulo, São Paulo, Brazil. "Universidade de São Paulo. São Paulo, São Paulo, Brazil.

How to cite this article:

Sala DCP, Okuno MFP, Taminato M, Castro CP, Louvison MCP, Tanaka OY. Breast cancer screening in Primary Health Care in Brazil: a systematic review. Rev Bras Enferm. 2021;74(3):e20200995. https://doi.org/10.1590/0034-7167-2020-0995

Corresponding author:

Danila Cristina Paquier Sala

E-mail: danilapaquiersala@gmail.com

EDITOR IN CHIEF: Antonio José de Almeida Filho ASSOCIATE EDITOR: Maria Saraiva

Submission: $09-27-2020$

Approval: 02-07-2021

\begin{abstract}
Objectives: to analyze care strategies for breast cancer screening in Primary Health Care in Brazil. Methods: this is a systematic review following the Cochrane Collaboration recommendations. Results: among 355 manuscripts, five were eligible. The patient navigation program by Community Health Agent stood out with the best result, among the strategies: flexibility of goals considering viability; community engagement; team training; active search of the target population by Community Health Agent; request for mammography by physicians; actions integrated to women's health; monitoring of mammography results, absent users, and population coverage by physician and nurse; and assessment of criteria for requesting screening mammography by means of an information system. The population coverage rate in the program ranged from $23 \%$ to $88 \%$. Conclusions: Primary Health Care in Brazil presents devices with potential to induce the production of care for breast cancer screening. Descriptors: Mass Screening; Breast Neoplasms; Primary Health Care; Public Policy; Brazil.
\end{abstract}

\section{RESUMO}

Objetivos: analisar estratégias de cuidado para o rastreio do câncer de mama na Atenção Primária à Saúde no Brasil. Métodos: trata-se de uma revisão sistemática seguindo as recomendações da Colaboração Cochrane. Resultados: entre 355 manuscritos, foram elegíveis cinco. $O$ programa de navegação do paciente pelo Agente Comunitário de Saúde destacou-se com o melhor resultado, dentre as estratégias: flexibilização das metas considerando a viabilidade; engajamento comunitário; treinamento da equipe; busca ativa da população-alvo pelo Agente Comunitário de Saúde; solicitação da mamografia por médicos; ações integradas à saúde da mulher; monitoramento do resultado da mamografia, das usuárias faltosas, e da cobertura da população por médico e enfermeiro e avaliação dos critérios de solicitação da mamografia de rastreamento por meio de sistema de informação. A taxa de cobertura da população no programa variou de $23 \%$ a $88 \%$. Conclusões: a Atenção Primária à Saúde brasileira apresenta dispositivos com potencial indutor à produção de cuidado do rastreio do câncer de mama. Descritores: Programas de Rastreamento; Neoplasias da Mama; Atenção Primária à Saúde; Política Pública; Brasil.

\section{RESUMEN}

Objetivos: analizar las estrategias de atención para el cribado del cáncer de mama en la Atención Primaria de Salud en Brasil. Métodos: se trata de una revisión sistemática siguiendo las recomendaciones de la Colaboración Cochrane. Resultados: de 355 manuscritos, cinco fueron elegibles. El programa de navegación del paciente por parte del Agente de Salud Comunitaria se destacó con mejor resultado, entre las estrategias: flexibilidad de las metas considerando la viabilidad; participación de la comunidad; entrenamiento en equipo; búsqueda activa de la población objetivo por parte del Agente de Salud Comunitaria; solicitud de mamografía por parte de los médicos; acciones integradas a la salud de la mujer; el seguimiento de los resultados de las mamografías, las usuarias ausentes y la cobertura poblacional por médico y enfermero, y la evaluación de los criterios para solicitar la mamografía de cribado mediante un sistema de información. La tasa de cobertura de la población en el programa osciló entre $23 \%$ y $88 \%$. Conclusiones: la Atención Primaria de Salud en Brasil presenta dispositivos con potencial para inducir la producción de cuidados para el cribado del cáncer de mama. Descriptores: Tamizaje Masivo; Neoplasias de la Mama; Atención Primaria de Salud; Política Pública; Brasil. 


\section{INTRODUCTION}

Breast cancer incidence and mortality rates are increasing in low and middle income countries, in contrast to high income countries ${ }^{(1)}$. Studies have shown the effectiveness of mammographic screening for breast cancer in reducing mortality and morbidity among women within a specific age range $\mathrm{e}^{(2-3)}$.

Screening programs aim to perform an exam or test that identifies, among a population group, people with the disease, but who still do not show signs or symptoms. The program can be implemented in an organized or opportunistic (unorganized) manner. In the organized call, from the registration of the entire eligible population, at regular intervals, the people who will benefit from the screening interventions are summoned ${ }^{(4)}$. The results of exams are systematically monitored, and the integrated health network guarantees vacancies for the other points of care, following the care line steps. Authors point out that the program management guarantees quality and better performance when screening ${ }^{(4-5)}$, favoring equal access, with a possible reflection in the reduction of social inequalities, compared to the opportunistic one ${ }^{(6)}$.

In Brazil, the practiced model is the opportunistic one, being recommended the offer of mammographic exam, in biennial intervals, to asymptomatic women, in the age group between 50 and 69 years; however, this process is not carried out for the entire eligible population and there is no guarantee of monitoring all care line steps ${ }^{(7-8)}$.

As a result, the National Health Survey showed that mammographic coverage among women aged 50 to 69 , without health insurance, is $51 \%(95 \% \mathrm{Cl} 49.5-52.4)$ below the target recommended by the Ministry of Health $(\mathrm{MoH})$ of $70 \%$. This distribution ranged from $31.9 \%(95 \% \mathrm{Cl} 29.1-34.8)$ in northern Brazil to $59.3 \%$ (95\% $\mathrm{Cl}$ 56.8-61.8) in southeastern Brazil(9), indicating low screening coverage. Another study, conducted in Minas Gerais, identified a prevalence of $21 \%$ in the repetition of screening mammogram at intervals of less than 18 months. This phenomenon characterizes over-screening and is concerned with overexposing women to the risks of mammography ${ }^{(10)}$, reflecting criticisms of mammography screening due to the effects of the investigation of false positives, as well as the damage of overdiagnosis, which, consequently, leads to overtreatment. women who would not manifest the clinical disease during their lifetime ${ }^{(11)}$.

Therefore, in Brazil, the opportunistic model, in addition to not guaranteeing access and quality of care, may be exposing women more to the risks than to the benefits of mammographic screening.

Considering the challenges pointed out and aiming to modify this panorama, evidence points out as a potent alternative the coordination of care by Primary Health Care (PHC) $)^{(12)}$. This locus can promote, in addition to access to mammography (MMG) ${ }^{(13)}$, person-centered care ${ }^{(14)}$, continuity of care ${ }^{(15)}$ and the recognition of social determinants ${ }^{(16)}$ in cancer care. Among the different configurations of PHC, those implementing the Family Health Strategy (FHS) have been consolidating in Brazil as a bet on the production of this care ${ }^{(17)}$.

This study is based on the assumption that the characteristics recommended by the FHS assistance modality in PHC implemented in Brazil can favor and enhance the performance of cancer screening.

Thus, the study seeks to understand how PHC has produced care strategies aimed at screening for breast cancer in Brazil, pointing out possible ways to qualify this care.

\section{OBJECTIVES}

To analyze care strategies for breast cancer screening in Primary Health Care in Brazil.

\section{METHODS}

This is a systematic review according to the Cochrane Collaboration guidelines ${ }^{(18)}$, with the guiding questions: what are the processes related to breast cancer screening developed and implemented as a care strategy in PHC in Brazil? What evidence that the identified strategies were effective for screening?

To elaborate the studies' search and assessment strategy, PICOS strategy was used, elucidated in Chart 1.

Chart 1 - Synthesis of the findings observed according to PICOS strategy

\begin{tabular}{|l|l|}
\hline P (problem) & Breast cancer. \\
\hline I (intervention) & $\begin{array}{l}\text { Care strategies for mammographic screening } \\
\text { for breast cancer in PHC in Brazil. }\end{array}$ \\
\hline C (comparison) & Not applicable. \\
\hline O (outcomes) & $\begin{array}{l}\text { Program coverage, adherence to the program, } \\
\text { disease detection rate, proportion of altered } \\
\text { results in screening MMGs, percentage } \\
\text { according to tumor extension, among other } \\
\text { indicators, assessed in the female population } \\
\text { aged 50 to 69 years. }\end{array}$ \\
\hline S (study design) & Comprehensive designs. \\
\hline
\end{tabular}

Articles with a source of primary and secondary data that addressed some type of assessment of mammographic screening achieved in the female population aged 50 to 69 years, involving PHC actions and services in Brazil were included. Studies that did not address the variables of interest were excluded.

The following databases and electronic libraries were consulted:VHL - Online System for Searching and Analyzing Medical Literature (MEDLINE/PubMed), Scientific Electronic Library Online (Scielo), Latin American and Caribbean Literature in Health Sciences (LILCHW), Embase, Scopus, and Web of Science, no initial time limit, but final on August 1, 2020. The following keywords and keywords were used: breast neoplasms, breast cancer, primary health care, screening, mammography, Brazil; extrapolated and adapted for each database, such as this search strategy on PubMed:

(((((“)breast neoplasms" [MeSH Terms] OR ("breast" [All Fields] AND"neoplasms"[All Fields])) OR"breast neoplasms"[All Fields]) OR ("breast" [All Fields] AND "cancer" [All Fields])) OR "breast cancer" [All Fields]) AND ()((c(()(((“diagnosis" [MeSH Subheading] OR "diagnosis" [All Fields]) OR "screening" [All Fields]) OR "mass screening" [MeSHTerms]) OR ("mass" [All Fields] AND"screening" [All Fields])) OR"mass screening" [All Fields]) OR "early detection of cancer" [MeSH Terms]) OR (("early"[All Fields] AND"detection" 
[All Fields]) AND "cancer" [All Fields])) OR "early detection of cancer" [All Fields]) OR "screen" [All Fields]) OR "screenings" [All Fields]) OR "screened" [All Fields]) OR "screens" [All Fields])) AND ((( (“"primary health care" [MeSHTerms] OR (("primary" [All Fields] AND"health" [All Fields]) AND"care" [All Fields])) OR"primary health care" [All Fields]) OR ("primary" [All Fields] AND"care" [All Fields])) OR "primary care" [All Fields])) AND ((("Brazil" [MeSH Terms] OR "Brazil"[All Fields]) OR"Brazils" [All Fields]) OR"Brazils"[All Fields])

Study selection, shown in Figure 1, was guided by the PRISMA recommendation ${ }^{(19)}$ (Main Items for Reporting Systematic Reviews and Meta-analyzes), and the classification of levels of scientific evidence was based on the model proposed by the Oxford Center for Evidence- Based ${ }^{(20)}$.

Chart 2 - Synthesis of concepts and parameters of some quality indicators of a breast cancer screening program in Brazil and Canada

\begin{tabular}{|c|c|c|c|}
\hline Indicator & Concept & $\begin{array}{l}\text { Brazil } \\
\text { parameters, } \\
\text { INCA* }\end{array}$ & $\begin{array}{l}\text { Canada } \\
\text { parameters }\end{array}$ \\
\hline $\begin{array}{l}\text { Participation } \\
\text { rate or } \\
\text { coverage of } \\
\text { the screening } \\
\text { program }\end{array}$ & $\begin{array}{l}\text { Percentage of } \\
\text { women in specific } \\
\text { age group who } \\
\text { performed the } \\
\text { screening, in a } \\
\text { given place and } \\
\text { period, in relation } \\
\text { to the total target } \\
\text { population. }\end{array}$ & $\begin{array}{l}70 \% \text { in the } \\
\text { age group } \\
\text { from } 50 \text { to } 69 \\
\text { years, MMG* } \\
\text { biennial. }\end{array}$ & $\begin{array}{l}\geq 70 \% \text { in the age } \\
\text { group } 50 \text { to } 69 \\
\text { years; } \text { MMG* in }^{*} 30 \text { months. }\end{array}$ \\
\hline Detection rate & $\begin{array}{l}\text { Number of } \\
\text { invasive breast } \\
\text { cancer cases } \\
\text { detected every } \\
1,000 \text { screening } \\
\text { tests. }\end{array}$ & Undefined. & $\begin{array}{l}>5 \text { per } \\
1,000 \text { initial } \\
\text { screenings; } \\
>3 \text { per 1,000 } \\
\text { screening } \\
\text { subsequent - } \\
\text { invasive cancer } \\
\text { (no in situ). }\end{array}$ \\
\hline $\begin{array}{l}\text { Proportion of } \\
\text { altered results } \\
\text { in screening } \\
\text { MMGs }\end{array}$ & $\begin{array}{l}\text { Percentage of } \\
\text { altered exams } \\
\text { in the screening } \\
\text { program. }\end{array}$ & $\begin{array}{l}\text { Undefined } \\
\text { parameter of } \\
\text { MMGs with } \\
\text { BI-RADS* } 0.4 \\
\text { and } 5 .\end{array}$ & $\begin{array}{l}<10 \% \text { in initial } \\
\text { screening; }<5 \% \\
\text { in subsequent } \\
\text { screenings. }\end{array}$ \\
\hline $\begin{array}{l}\text { Percentage } \\
\text { according } \\
\text { to tumor } \\
\text { extension }\end{array}$ & $\begin{array}{l}\text { Percentage of } \\
\text { tumor detection } \\
\text { in screening the } \\
\text { size of invasive } \\
\text { tumors with size } \\
\leq 15 \mathrm{~mm} \text { of the } \\
\text { largest diameter } \\
\text { determined by } \\
\text { the best evidence } \\
\text { (pathology, } \\
\text { radiology, and } \\
\text { clinic). }\end{array}$ & Undefined. & $\begin{array}{l}50 \text { to } 69 \text { years } \\
\text { old: }>50 \% \\
\text { detection of } \\
\text { invasive tumors } \\
\text { by screening } \\
\text { with } \leq 15 \mathrm{~mm} \text {. }\end{array}$ \\
\hline $\begin{array}{l}\text { Program } \\
\text { support }\end{array}$ & $\begin{array}{l}\text { Adherence/ } \\
\text { retention rate is } \\
\text { the estimated } \\
\text { percentage of the } \\
\text { target population } \\
\text { that returns to } \\
\text { screening within } \\
\text { the estimated } \\
\text { period. }\end{array}$ & Undefined. & $\begin{array}{l}\geq 75 \% \text { in the } \\
50-67 \text { age } \\
\text { group in the 1st } \\
\text { screening; } \geq 90 \% \\
\text { in subsequent } \\
\text { years. }\end{array}$ \\
\hline
\end{tabular}

Note: *INCA - Brazilian National Cancer Institute; MMG - mammography; BI-RADS - Breast Imaging-Reporting and Data System.
To analyze the effectiveness of the identified processes, the best indicator of the result of screening programs would be a decrease in the mortality rate in the region covered; however, no study has been found presenting these results in Brazil. Therefore, a comprehensive analysis was chosen based on the main indicators in Brazil (21-22), complemented with Canadian parameters ${ }^{(23)}$, synthesized in Chart 2. Other indicators were also considered, presented and discussed by the authors of the articles included in the sample.

The studies identified by the initial search strategy were assessed by two authors, following the inclusion criteria and study selection. Titles and abstracts were independently assessed by each of the two authors, strictly following the inclusion and exclusion criteria defined in the research protocol. In cases where titles and abstracts were not clarifying, the article was read in full, and in cases of doubt, a third reviewer was asked to issue an opinion regarding the study inclusion or exclusion.

\section{RESULTS}

The initial search identified 355 publications after applying the inclusion and exclusion and reading criteria, 5 of which were included for analysis (Figure 1).

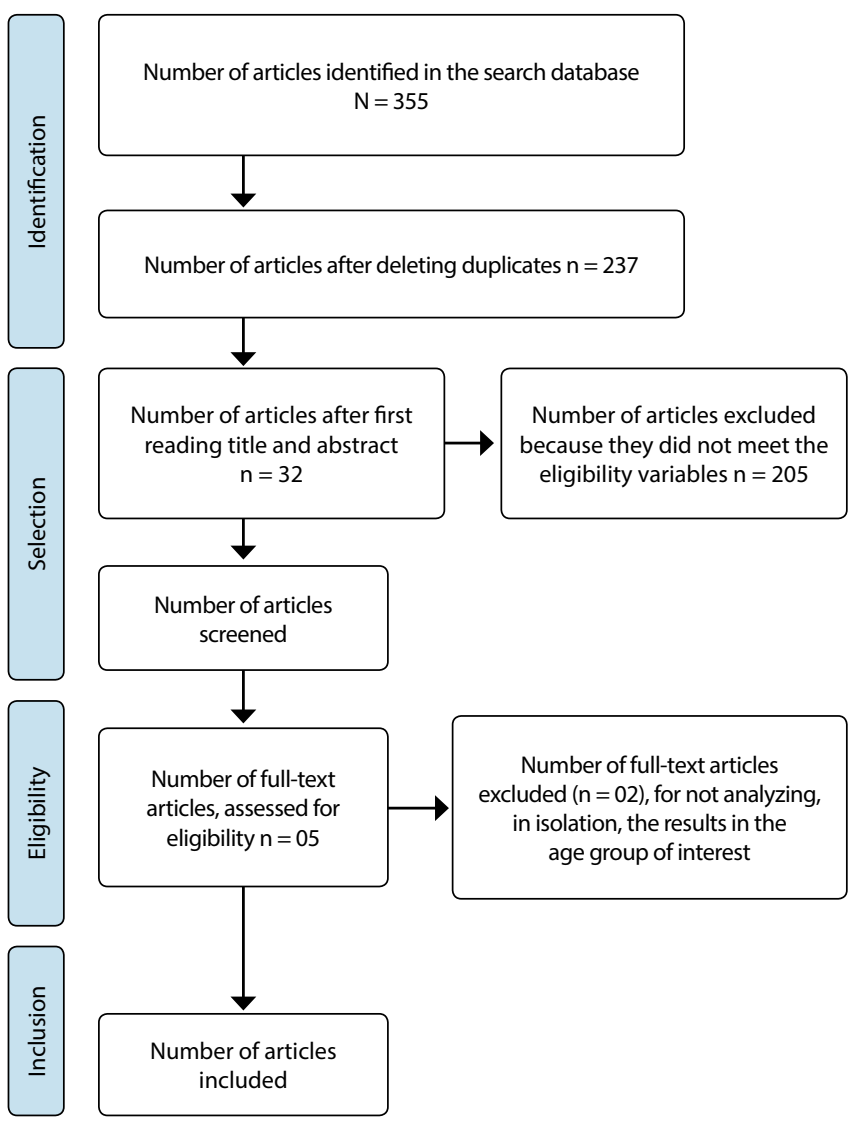

Figure 1 - Diagram of the article selection process according to PRISMA recommendation

Chart 3 presents the characteristics of each study, the care strategies aimed at screening for breast cancer as well as the results of the assessed indicators. 
Chart 3 - Characteristics of studies, care strategies for screening breast cancer in Primary Health Care in Brazil, indicators and results, Brazil, 2020

\begin{tabular}{|c|c|c|c|c|c|c|}
\hline Authors, year & Objective & $\begin{array}{l}\text { Method/ } \\
\text { Level of } \\
\text { evidence }\end{array}$ & $\begin{array}{l}\text { Population/ } \\
\text { Participants }\end{array}$ & Strategies & Indicators & Results \\
\hline $\begin{array}{l}\text { Barreto ALSB, } \\
\text { Mendes MFM, } \\
\text { Thuler LCS. } \\
2012^{(24)}\end{array}$ & $\begin{array}{l}\text { Assess the actions of a } \\
\text { program entitled Um Beijo } \\
\text { Pela Vida, developed in a } \\
\text { municipality in northeastern } \\
\text { Brazil, aiming to expand the } \\
\text { treatment of breast cancer } \\
\text { screening in women registered } \\
\text { by FHS. }\end{array}$ & $\begin{array}{l}\text { Cross-sectional } \\
\text { description } / 4\end{array}$ & 3,608 women & $\begin{array}{l}\text { Active search for women eligible } \\
\text { for } \mathrm{CHW}^{*} \text {. Team training and } \\
\text { qualification. }\end{array}$ & $\begin{array}{l}\text { MMG coverage of } \\
\text { target population } \\
\text { screening ( } 50 \text { to } \\
69 \text { years old }) .\end{array}$ & $56.7 \%$ \\
\hline $\begin{array}{l}\text { Haikel Jr RL, } \\
\text { Mauad EC, } \\
\text { Silva TB, Mattos } \\
\text { JSC, Chala LF, } \\
\text { Longatto-Filho } \\
\text { A, et al. 2012 }\end{array}$ & $\begin{array}{l}\text { Assess the results of the first } \\
2 \text { years of an MMG program } \\
\text { implemented with mobile and } \\
\text { immovable mammographic } \\
\text { unit in rural region of the state } \\
\text { of São Paulo, Brazil. }\end{array}$ & $\begin{array}{l}\text { Cross-sectional } \\
\text { description } / 4\end{array}$ & 17,964 MMGs & $\begin{array}{l}\text { Invitation of the eligible population } \\
\text { made by } \mathrm{CHW}^{*} \text { (active search) and } \\
\text { by physicians. Team training and } \\
\text { qualification. }\end{array}$ & $\begin{array}{l}\text { Detection rate } \\
\text { (50-59 years old) } \\
\text { (60-69 years old). }\end{array}$ & $\begin{array}{l}3.4 / 1,000 \\
6.7 / 1,000\end{array}$ \\
\hline $\begin{array}{l}\text { Nasser MA, } \\
\text { Nemes MIB, } \\
\text { Andrade MC, } \\
\text { Prado RR, } \\
\text { Castanheira } \\
\text { ERL. 2017 } \\
\end{array}$ & $\begin{array}{l}\text { Assess the performance in } \\
\text { sexual and reproductive health } \\
\text { of PHC services of the Brazilian } \\
\text { Unified Health System (Sistema } \\
\text { Único de Saúde), in the state of } \\
\text { São Paulo. }\end{array}$ & $\begin{array}{l}\text { Evaluative } \\
\text { study/4 }\end{array}$ & $\begin{array}{l}2,735 \mathrm{PHC} \\
\text { services*. }\end{array}$ & $\begin{array}{l}\text { Assessment of the screening MMG } \\
\text { request criteria for age group ( } 50 \\
\text { and } 69 \text { years old), asymptomatic, } \\
\text { repeating at biennial intervals, } \\
\text { information system - QualiAB } \\
\text { Program*. }\end{array}$ & $\begin{array}{l}\text { Adequacy to the } \\
\text { criteria of MMG } \\
\text { request. }\end{array}$ & $11.8 \%$ \\
\hline \multirow{6}{*}{$\begin{array}{l}\text { Romero LS, } \\
\text { Shimocomaqui } \\
\text { GB, Medeiros } \\
\text { ABR. Piauí. } \\
\text { 2017(27) }\end{array}$} & \multirow{6}{*}{$\begin{array}{l}\text { Report the experience carried } \\
\text { out at the São Miguel II Basic } \\
\text { Health Unit, Miguel Alves, Piauí, } \\
\text { focusing on the prevention } \\
\text { and control of cervical and } \\
\text { breast cancers. }\end{array}$} & \multirow{6}{*}{$\begin{array}{l}\text { Experience } \\
\text { report } / 5\end{array}$} & \multirow{6}{*}{$1 \mathrm{PHC}$ service. } & Community engagement. & \multirow{3}{*}{$\begin{array}{l}\text { Screening MMG } \\
\text { request to target } \\
\text { population ( } 50 \text { to } \\
69 \text { years old). }\end{array}$} & \multirow{3}{*}{$88.1 \%$} \\
\hline & & & & MMG request by physician. & & \\
\hline & & & & $\begin{array}{l}\text { Monitoring of the results of MMG, } \\
\text { missing users and coverage of the } \\
\text { population by physician and nurse. }\end{array}$ & & \\
\hline & & & & $\begin{array}{l}\text { Integrated actions to women's health } \\
\text { (prevention of breast, cervical cancer } \\
\text { and risk factor assessment). }\end{array}$ & \multirow{3}{*}{$\begin{array}{l}\text { MMG coverage of } \\
\text { target population } \\
\text { screening ( } 50 \text { to } \\
69 \text { years old). }\end{array}$} & \multirow{3}{*}{$23 \%$} \\
\hline & & & & Team training and qualification. & & \\
\hline & & & & $\begin{array}{l}\text { Flexibility of goals considering } \\
\text { viability. }\end{array}$ & & \\
\hline \multirow{2}{*}{$\begin{array}{l}\text { Gioia S, } \\
\text { Brigagão L, } \\
\text { Torres C, Lima } \\
\text { A, Medeiros M. } \\
2019^{(28)}\end{array}$} & \multirow{2}{*}{$\begin{array}{l}\text { Establish the viability of } \\
\text { patients' navigation program } \\
\text { in a community in the city of } \\
\text { Rio de Janeiro; identify barriers } \\
\text { to mammographic screening; } \\
\text { mammographic coverage } \\
\text { of } 70 \% \text { of women recruited } \\
\text { between } 50 \text { and } 69 \text { years old. }\end{array}$} & \multirow[t]{2}{*}{$\begin{array}{l}\text { Quantitative } \\
\text { qualitative/4 }\end{array}$} & \multirow[t]{2}{*}{497 women. } & \multirow[t]{2}{*}{$\mathrm{CHW}^{*}$ patient navigation program. } & $\begin{array}{l}\text { MMG coverage of } \\
\text { target population } \\
\text { screening ( } 50 \text { to } \\
69 \text { years old). }\end{array}$ & $88 \%$ \\
\hline & & & & & User satisfaction. & $100 \%$ \\
\hline
\end{tabular}

Note: *CHW - Community Health Worker; QualiAB - Primary Care Monitoring and Assessment System; PHC - Primary Health Care.

Chart 4 - Synthesis of care strategies for screening breast cancer in Primary Health Care in Brazil, Brazil, 2020

\begin{tabular}{|l|}
\hline Flexibility of goals considering feasibility. \\
\hline Community engagement. \\
\hline Team training and qualification. \\
\hline Active search of the target population by the Community Health Worker. \\
\hline Patient navigation program by the Community Health Worker. \\
\hline Invitation of the target population by physicians. \\
\hline MMG request by physicians. \\
\hline Actions integrated to women's health. \\
\hline $\begin{array}{l}\text { Monitoring the results of MMG, absent users and the coverage of the } \\
\text { program by a physician and nurse. }\end{array}$ \\
\hline $\begin{array}{l}\text { Assessment of the criteria for requesting MMG through information } \\
\text { systems. }\end{array}$ \\
\hline Note:MMG - mammography.
\end{tabular}

It can be seen that three studies used a quantitative approach $(60 \%)$, one, mixed (20\%), and one, qualitative (20\%). All studies adopted a descriptive design, expressing results with levels of evidence 4 (80\%) and 5 (20\%).

Chart 4 synthesizes the processes, identified in the researched literature, related to breast cancer screening developed and implemented as a care strategy in PHC in Brazil.

\section{DISCUSSION}

Public policies for secondary prevention of breast cancer have required managers and $\mathrm{PHC}$ teams to implement MMG as a strategy for screening breast cancer in women aged 50 to 69 years. However, the unique production identified in this review reveals the lack of a directive to support this process. 
PHC professionals, when faced with the implementation of evidence-oriented practice, take into account the need to develop strategies not limited to MMG's request, but also to the context, organization and actors involved, dimensions pointed out by other researchers ${ }^{(29)}$. The literature published on implementation science deepens this type of approach, and with theoretical models, frameworks and comprehensive methodologies, it has been proven that considering barriers and facilitators of the real context of health systems and services increases the chance of success in the implementation and sustainability of actions, programs and policies ${ }^{(30)}$.

When analyzing the experience reported in a single service that reached a percentage of $88.1 \%$ of MMG requests when adopting a set of strategies, it was found that only $23 \%$ of these women underwent MMG, due to strangulation in Specialized Care (SC) ${ }^{(27)}$. The difficulty in accessing MMG by women of high social vulnerability is documented in $\mathrm{Brazi}^{(31)}$. Having $\mathrm{PHC}$ registration with FHS has been suggested as a possible barrier ${ }^{(32)}$. These findings demonstrate that, even with the adoption of a strategic, participative planning and application of numerous strategies, aiming at the reorganization of the work process of teams for implementing the screening, there is a need to create new strategies that integrate and articulate services of the care network and municipal and state managers ${ }^{(33)}$.

On the other hand, when the request and execution of MMG were made by SC, the coverage rate achieved was $56.7 \%{ }^{(24)}$ and the cancer detection rate was 3.4 to 6.7 cases per $1,000 \mathrm{MMGs}^{(25)}$. In these studies, it was found that the role of PHC was focused on identifying and attracting the target population, and, for this, it brought together activities, such as active search for $\mathrm{CHW}$ and invitation by physicians. The coverage identified was less than the recommended target of $70 \%$, and the detection rate, in the age group between 60 and 69 years, above the ideal parameter, reflected the need for the program's sustainability. These findings encourage reflections on what the role of $\mathrm{PHC}$ should be in the quest to make mammographic screening more effective. This challenge is corroborated by the data from QualiAB, which identified the adequacy of only $11.8 \%$ of the MMG request criteria in $\mathrm{PHC}$ regarding the age range of the target population and frequency ${ }^{(26)}$.

Attention to cancer has been built around the disease, with an emphasis on diagnosis and treatment, focused on specialized care. With technological advances, preventive practices, including screening, have been encouraged as a way to achieve early detection and cure of the disease. Practices associated with encouraging the consumption of interventions characterize the reproduction of a concept about the disease, reflected in the care model recommended today. The maintenance of a biologically based model, with normative prescriptions that reduce patients' autonomy and their co-responsibility for care in mammographic screening ${ }^{(34)}$, reproduce a curative and inefficient model.

By developing the skills expected in PHC beyond the gateway, the strategy of patient navigation by a Community Health Worker $(\mathrm{CHW})$, in addition to showing the best result ${ }^{(28)}$, allowed us to move towards a vision that considered users and their subjectivities in the social process of building the disease. The patient navigation program consists of a trained team that helps patients to overcome modifiable barriers to care based on a personalized approach $^{(35)}$. It was originally developed to provide support to vulnerable populations, a strategy that has been increasingly used in chronic conditions, particularly cancer, in $\mathrm{PHC}$ services ${ }^{(36)}$. In Brazil, although CHW has been shown to be the actor with the greatest capacity for articulation between $\mathrm{PHC}$ and the community ${ }^{(37)}$, the adoption of this strategy has been carried out, carefully, in small, well-implemented and well-assessed programs to be progressively expanded ${ }^{(38)}$.

It is important to highlight other identified strategies that, although they have not been tested in isolation, were considered key elements for the implementation process. Flexibility of goals considering feasibility is one of them. Planning, taking into account what is ideal, and what is actually possible, considering the real context of services, resource limitations and the population's health needs, is a fundamental measure. It is not a question of mistrust, but of an attitude of caution regarding the resources mobilized ${ }^{(39)}$. Researchers emphasize that viability can be considered an implementation outcome, considering that its results serve as an analysis of necessary preconditions to achieve the desired changes ${ }^{(40)}$.

Training with sharing of practices among the team was a work process strategy observed in this review. This characteristic points to the importance of providing the production of team care in $\mathrm{PHC}$ as a space that considers tensions and disputes among professionals, i.e., it considers the political production of work to be a strategic part for the implementation of a program ${ }^{(41)}$.

Actions encompassing attention to breast and cervical cancer, with analysis of risk factors, encompass one of the dimensions of comprehensiveness, by producing a care plan that favors attention to women's health. This approach is still a challenge to be overcome in the production of work in the daily routine of PHC services ${ }^{(26,41)}$.

Nurses' participation in the work process demonstrates the political strengthening of this professional, commitment to care and the development of autonomy. Over the years, more and more $\mathrm{PHC}$ care management activities have been their responsibility, bringing together a set of actions in addition to nursing consultation. A study points out nurses' contributions in the coordination of care and in the reduction of barriers to access to screening ${ }^{(42)}$.

The request for exams has recently been included in the list of advanced nursing practice actions in PHC in Latin America(43). Laws and policies focused on breast cancer care go back to a pre-SUS period, and in 1997, the Federal Nursing Council ${ }^{(44)}$ declared that the ministerial guidelines would serve as a basis for prescribing guidelines for nurses in the country. It took 14 years for the Regional Nursing Council ${ }^{(45)}$, of São Paulo, to legitimize the request for a mammographic exam by nurses, a fact that is still far from being practiced in the national territory, a gap verified in this review.

The most used indicators for assessing the screening program's effectiveness were mammographic examination request and coverage, the cancer detection rate, user satisfaction and the adequacy to the normative criteria of MMG screening. In Brazil, there is a diversity of national secondary databases that have supported the assessment process. The Brazilian National Program for Improvement of Access and Quality of Primary Care (PMAQ-AB 
- Programa Nacional de Melhoria de Acesso e da Qualidade da Atenção Básica), e-SUS AB, the Ambulatory Information System (AIS), and a subsystem of AIS, the Breast Cancer Information System (SISMAMA - Sistema de Informação do câncer de mama), which has been gradually replaced by the Brazilian Cancer Information System (CIS) since 2013, are some of these examples. There are also regional databases, such as QualiAB, a tool that offers PHC managers and teams the opportunity to assess PHC services; however, because it does not have mandatory adherence by municipalities in São Paulo, it has limited regional data ${ }^{(46)}$.

Some of the aforementioned databases have limitations for the screening of breast cancer, since the information is either referring to procedures or does not yet allow the full integration of information between services, making monitoring in the care line difficult ${ }^{(47)}$. Such issues compromise strategies, such as the monitoring and assessment of processes in $\mathrm{PHC}$, and the case management shared between PHC and SC. In most of the studies that comprised the sample, monitoring and assessment of processes were carried out, in an isolated and centralized manner, by $\mathrm{PHC}$ or SC, without the use of standardized information systems. The use of information systems is considered a tactical device with the potential to improve monitoring and the incorporation of assessment in health services ${ }^{(48)}$.

Stakeholders, implementers and policy makers, multidisciplinary researchers, professionals and the community need to get closer, discuss the evidence and rethink practices, aiming at building safe care in cancer care for women ${ }^{(49)}$.

There is a need to address relevant problems, use distinct and sensitive methods that are guided by well-defined evaluative issues and geared to each level of decision (policy makers, implementers and beneficiaries). In this regard, the strengthening and engagement of interested people who are in the concrete reality of services and the community are essential strategies ${ }^{(50)}$ for the improvement of care management.

\section{Study limitations}

The present study showed that national production is concentrated in studies with a low level of evidence, however fundamental for decision-making, consolidation of public policies for cancer care and incorporation of technologies. Another limitation was related to the difficulty in the combined analysis of studies due to the different populations, interventions and outcomes adopted, making it impossible to carry out a meta-analysis.
Low production found on the theme, as well as the heterogeneity of the methodological designs, shows the unique results of this investigation, reflecting an overview of low and middle income countries with little production in breast cancer prevention. Therefore, the results of this study were considered the best evidence.

\section{Contributions to nursing and health}

The results point to ways that lead to the implementation of strategies to manage screening in the primary network in Brazil, mainly through the $\mathrm{CHW}$ patient navigation program. It is essential to indicate as a target image of practices in PHC in Brazil the regulation of MMG's offer so that it is inserted in systematic breast cancer screening programs with clear and viable guidelines. The PHC contribution is added to the organization of actions to identify and attract the program's target population as a strategy to expand coverage and participation. Teamwork with clinic management that allows indication of evidence-based MMG, in addition to monitoring and case-by-case assessment, favoring access to SC integrated to the oncology network, subsidized by information systems, are incipient strategies in Brazilian PHC.

\section{CONCLUSIONS}

PHC presents devices with potential to induce the user's first contact, mainly using the patient navigation strategy through $\mathrm{CHW}$. Also highlighted as contributions to the development of actions by PHC, other key elements: flexibility of program goals considering feasibility analysis; community engagement; team training; active search of the target population by $\mathrm{CHW}$; invitation to participate in the program by physicians; MMG request by physicians; actions integrated to women's health; monitoring of altered results, missing users and coverage of the target population by physician and nurse; assessment of MMG request criteria for screening by means of an information system.

It is hoped, with these results, to contribute to a more in-depth critical discussion about the routine of $\mathrm{PHC}$ services, pointing out some strategies for the implementation of the public policy for breast cancer screening, ordered by PHC with FHS. Moreover, it is expected to foster research in this area, valuing this locus of care and aiming to provide subsidies for decision-making for policy makers and implementers, managers, health professionals and the population of Brazil and other developing countries.

\section{REFERENCES}

1. DeSantis CE, Bray F, Ferlay J, Lortet-Tieulent J, Anderson BO, Jemal A. International variation in female breast cancer incidence and mortality rates. Cancer Epidemiol Biomarkers Prev. 2015;24(10):1495-506. https://doi.org/10.1158/1055-9965.EPI-15-0535

2. Allemani C, Weir HK, Carreira H, Harewood R, Spika D, Wang X-S, et al. Global surveillance of cancer survival 1995-2009: analysis of individual data for 25676887 patients from 279 population-based registries in 67 countries (CONCORD-2). Lancet. 2015;385(9972):977-1010. https:// doi.org/10.1016/S0140-6736(14)62038-9

3. Siu AL. Screening for Breast Cancer: U.S. Preventive Services Task Force Recommendation Statement. Ann Intern Med. $2016 ; 164(4): 279-96$. https://doi.org/10.7326/M15-2886

4. Miles A, Cockburn J, Smith RA, Wardle J. A perspective from countries using organized screening programs. Cancer. 2004;101(S5):1201-13. https://doi.org/10.1002/cncr.20505 
Breast cancer screening in Primary Health Care in Brazil: a systematic review Sala DCP, Okuno MFP, Taminato M, Castro CP, Louvison MCP, Tanaka OY.

5. Lauby-Secretan B, Scoccianti C, Loomis D, Benbrahim-Tallaa L, Bouvard V, Bianchini F, et al. Breast-Cancer Screening - Viewpoint of the IARC Working Group. N Engl J Med. 2015;372(24):2353-8. https://doi.org/10.1056/NEJMsr1504363

6. Palencia L, Espelt A, Rodriguez-Sanz M, Puigpinos R, Pons-Vigues M, Pasarin MI, et al. Socio-economic inequalities in breast and cervical cancer screening practices in Europe: influence of the type of screening program. Int J Epidemiol. 2010;39(3):757-65. https://doi. org/10.1093/ije/dyq003

7. Silva RCF, Hortale VA. Rastreamento do Câncer de Mama no Brasil: quem, como e por quê? Rev Bras Cancerol [Internet]. 2012 [cited 2019 Aug 25];58(1):67-71. Available from: http://www1.inca.gov.br/rbc/n_58/v01/pdf/10b_artigo_opiniao_rastreamento_cancer_mama_brasil_ quem_como_por_que.pdf

8. Migowski A, Azevedo e Silva G, Dias MBK, Diz MDPE, Sant'Ana DR, Nadanovsky P. Guidelines for early detection of breast cancer in Brazil. II - New national recommendations, main evidence, and controversies. Cad Saude Publica. 2018;34(6):e00074817. https://doi. org/10.1590/0102-311x00074817

9. Azevedo e Silva G, Souza-Jr PRB, Damacena GN, Szwarcwald CL. Early detection of breast cancer in Brazil: Data from the National Health Survey, 2013. Rev Saude Publica. 2017;51:1S-8S. https://doi.org/10.1590/S1518-8787.2017051000191

10. Rodrigues TB, De Stavola B, Bustamante-Teixeira MT, Guerra MR, Nogueira MC, Fayer VA, et al. Mammographic over-screening: evaluation based on probabilistic linkage of records databases from the breast cancer information system (SISMAMA). Cad Saude Publica. 2019;35(1):e00049718. https://doi.org/10.1590/0102-311x00049718

11. Gøtzsche PC, Jørgensen KJ. Screening for breast cancer with mammography. Cochrane Database Syst Rev. 2013;(6):CD001877. https://doi. org/10.1002/14651858.CD001877.pub5

12. Paim J, Travassos C, Almeida C, Bahia L, Macinko J. The Brazilian health system: history, advances, and challenges. Lancet. 2011;377(9779):1778-97. https://doi.org/10.1016/S0140-6736(11)60054-8

13. Ramos ACV, Alves LS, Berra TZ, Popolin MP, Arcoverde MAM, Campoy LT, et al. Family Health Strategy, private health care, and inequalities in access to mammography in Brazil. Rev Panam Salud Pública. 2018;42:e166. https://doi.org/10.26633/rpsp.2018.166

14. Selby K, Bartlett-Esquilant G, Cornuz J. Personalized cancer screening: helping primary care rise to the challenge. Public Health Rev. 2018;39:4. https://doi.org/10.1186/s40985-018-0083-x

15. Fisher KJ, Lee J-H, Ferrante JM, McCarthy EP, Gonzalez EC, Chen R, et al. The effects of primary care on breast cancer mortality and incidence among Medicare beneficiaries. Cancer. 2013;119(16):2964-72. https://doi.org/10.1002/cncr.28148

16. Mishra SI, DeForge B, Barnet B, Ntiri S, Grant L. Social determinants of breast cancer screening in urban Primary Care practices: a community-engaged formative study. Women's Health Iss. 2012;22(5):e429-38. https://doi.org/10.1016/j.whi.2012.06.004

17. Macinko J, Harris MJ. Brazil's family health strategy - Delivering community-based primary care in a universal health system. N Engl J Med. 2015;372(23):2177-81. https://doi.org/10.1056/NEJMp1501140.

18. Higgins JPT, Thomas J, Chandler J, Cumpston M, Li T, Page MJ, Welch VA (editors). Cochrane Handbook for Systematic Reviews of Interventions version 6.0 (updated July 2019) [Internet]. Cochrane, 2019 [cited 2019 Sep 3]. Available from: www.training.cochrane.org/ handbook

19. Galvão TF, Pansani TSA, Harrad D. Principais itens para relatar Revisões sistemáticas e Meta-análises: a recomendação PRISMA. Epidemiol Serv Saúde. 2015;24(2):335-42. https://doi.org/10.5123/S1679-49742015000200017

20. OCEBM Levels of Evidence Working Group. "The Oxford Levels of Evidence 2" [Internet]. Oxford Centre for Evidence-Based Medicine. 2011 [cited 2019 Sep 3]. Available from: https://www.cebm.net/2016/05/ocebm-levels-of-evidence/

21. Ministério da Saúde (BR). Secretaria de Atenção à Saúde. Departamento de Atenção Básica. Controle dos cânceres do colo do útero e de mama.Cadernos de Atenção Básica n.13 [Internet]. 2nd ed. Brasília: Ministério da Saúde; 2013 [cited 2019 Aug 25]. 124 p. Available from: http://bvsms.saude.gov.br/bvs/publicacoes/controle_canceres_colo_utero_2013.pdf

22. Ministério da Saúde (BR). Instituto Nacional de Câncer José Alencar da Silva. Ficha Técnica Indicadores Mama 2014 [Internet]. INCA. Rio de Janeiro; 2014 [cited 2019 Aug 25]. Available from: https://www.inca.gov.br/sites/ufu.sti.inca.local/files//media/document//ficha-tecnicaindicadores-mama-2014.pdf

23. Canadian Partnership Against Cancer. Breast Cancer Screening in Canada: Monitoring and Evaluation of Quality Indicators - Results Report. January 2011 to December 2012[Internet]. Toronto; 2017 [cited 2019 Aug 29]. Available from: https://www.partnershipagainstcancer.ca/ topics/breast-cancer-screening-quality-indicators-2017/

24. Barreto ASB, Mendes MFM, Thuler LCS. Avaliação de uma estratégia para ampliar a adesão ao rastreamento do câncer de mama no Nordeste brasileiro. Rev Bras Ginecol Obstet. 2012;34(2):86-91. https://doi.org/10.1590/S0100-72032012000200008

25. Haikel RL, Mauad EC, Silva TB, Mattos JC, Chala LF, Longatto-Filho A, et al. Mammography-based screening program: preliminary results from a first 2-year round in a Brazilian region using mobile and fixed units. BMC Womens Health. 2012;12(1):32. https://doi.org/10.1186/1472-6874-12-32

26. Nasser MA, Nemes MIB, Andrade MC, Prado RR, Castanheira ERL. Avaliação na atenção primária paulista: ações incipientes em saúde sexual e reprodutiva. Rev Saude Publica. 2017;51:77. https://doi.org/10.11606/s1518-8787.2017051006711

27. Romero LS, Shimocomaqui GB, Medeiros ABR. Intervenção na prevenção e controle de câncer de colo uterino e mama numa unidade básica de saúde do nordeste do Brasil. Rev Bras Med Fam Com. 2017;12(39):1-9. https://doi.org/10.5712/rbmfc12(39)1356. 
Breast cancer screening in Primary Health Care in Brazil: a systematic review Sala DCP, Okuno MFP, Taminato M, Castro CP, Louvison MCP, Tanaka OY.

28. Gioia S, Brigagão L, Torres C, Lima A, Medeiros M. The implementation of patient navigation to improve mammography coverage and access to breast cancer care in rio de janeiro. Mastol. 2019;29(4):186-92. https://doi.org/10.29289/25945394201920190006

29. Lau R, Stevenson F, Ong BN, Dziedzic K, Treweek S, Eldridge S et al. Achieving change in primary care-causes of the evidence to practice gap: systematic reviews of reviews. Implement Sci. 2016;11:40. https://doi.org/10.1186/s13012-016-0396-4

30. Brownson RC, Colditz GA, Proctor EK. Dissemination and Implementation Research in Health:Translating science to practice. Second Ed. New York: Oxford University Press; 2018.

31. Bezerra HS, Melo TFV, Barbosa JV, Feitosa EELC, Sousa LCM. Evaluation of access to mammographies in Brazil and socioeconomic indicators: a space study. Rev Gaúcha Enferm. 2018;39:e20180014. https://doi.org/10.1590/1983- 1447.2018.20180014

32. Barbosa YC, Oliveira AGC, Rabêlo PPC, Silva FS, Santos AM. Fatores associados à não realização de mamografia: Pesquisa Nacional de Saúde, 2013. Rev Bras Epidemiol. 2019;22:e190069. https://doi.org/10.1590/1980-549720190069

33. Bousquat $A$, Giovanella L, Campos EMS, Almeida PF, Martins CL, Mota PHS, et al. Atenção primária à saúde e coordenação do cuidado nas regiões de saúde: perspectiva de gestores e usuários. Cienc Saude Colet. 2017;22(4):1141-54. https://doi. org/10.1590/1413-81232017224.28632016

34. Tesser CD. Cuidado(!) na prevenção do câncer: ética, danos e equívocos. Rev Bras Med Fam Com. 2013;9(31):180-2. https://doi.org/10.5712/ rbmfc9(31)859

35. Pautasso FF, Lobo TC, Flores CD, Caregnato RCA. Nurse Navigator: desenvolvimento de um programa para o Brasil. Rev Latino-Am Enfermagem. 2020;28:e3275. https://doi.org/10.1590/1518-8345.3258.3275

36. McBrien KA, Ivers N, Barnieh L, Bailey JJ, Lorenzetti DL, Nicholas D, et al. Patient navigators for people with chronic disease: a systematic review. PLoS One. 2018;13(2):e0191980. https://doi.org/10.1371/journal.pone.0191980

37. Pinto ESG, Queiroz RF, Carreiro GSP, Morais LJ, Medeiros ER, Villa TCS. Coordination of health care with the community in the clinical management of tuberculosis. Rev Bras Enferm. 2018;71(3):1122-7. https://doi.org/10.1590/0034-7167-2017-0255

38. Hodgins S. Learning from Community Health Worker Programs, Big and Small. Glob Health: Sci Pract. 2020; 8(2):147-9. https://doi. org/10.9745/GHSP-D-20-00244

39. Hartz ZMA, Contandriopoulos A-P. Integralidade da atenção e integração de serviços de saúde: desafios para avaliar a implantação de um "sistema sem muros." Cad Saude Publica. 2004;20(suppl 2):S331-6. https://doi.org/10.1590/S0102-311X2004000800026

40. Proctor E, Silmere H, Raghavan R, Hovmand P, Aarons G, Bunger A, et al. Outcomes for implementation research: conceptual distinctions, measurement challenges, and research agenda. Adm Policy Ment Health. 2011;38(2):65-76. https://doi.org/10.1007/s10488-010-0319-7

41. Carnut L. Cuidado, integralidade e atenção primária: articulação essencial para refletir sobre o setor saúde no Brasil. Saúde Debate. 2017;41(115):1177-86. https://doi.org/10.1590/0103-1104201711515

42. Lourenço TS, Mauad EC, Vieira RA da C. Barriers in the breast cancer screening and the role of nursing: an integrative review. Rev Bras Enferm. 2013;66(4):585-91. https://doi.org/10.1590/s0034-71672013000400018

43. Miranda Neto MV, Rewa T, Leonello VM, Oliveira MAC. Advanced practice nursing: a possibility for Primary Health Care? Rev Bras Enferm. 2018;71(suppl 1):716-21. https://doi.org/10.1590/0034-7167-2017-0672

44. Conselho Federal de Enfermagem. Resolução COFEN-195/1997. Dispõe sobre a solicitação de exames de rotina e complementares por enfermeiro [Internet]. 1997[cited 2019 Aug 25]. Available from: http://www.cofen.gov.br/resoluo-cofen-1951997_4252.html

45. Conselho Regional de Enfermagem de São Paulo. PARECER COREN- SP GAB No28/2011 Solicitação de mamografia[Internet]. 2011[cited 2019 Aug 25]:1-4. Available from: https://portal.coren-sp.gov.br/wp-content/uploads/2013/07/parecer_coren_sp_2011_28.pdf

46. Castanheira ERL, Nemes MIB, Zarili TFT, Sanine PR, Corrente JE. Avaliação de serviços de Atenção Básica em municípios de pequeno e médio porte no estado de São Paulo: resultados da primeira aplicação do instrumento QualiAB. Saude Debate. 2014;38(103):679-91. https://doi. org/10.5935/0103-1104.20140063

47. Tomazelli JG, Girianelli VR, Azevedo e Silva G. Mulheres rastreadas para câncer de mama: acompanhamento por meio dos sistemas de informações em saúde, 2010-2012. Epidemiol Serv Saúde. 2018;27(3):e2017445. https://doi.org/10.5123/s1679-49742018000300005

48. Drumond Jr M. Análise de dados secundários nos serviços de saúde. In: Tanaka OY, Ribeiro EL, Almeida CAL. Avaliação em Saúde: contribuições para incorporação no cotidiano. Rio de Janeiro: Atheneu; 2017. p.115-23.

49. Peters DH, Peters MA, Wickramasinghe K, Osewe PL, Davidson PM. Asking the right question: implementation research to accelerate national non-communicable disease responses. BMJ. 2019;365:11868. https://doi.org/10.1136/bmj.l1868

50. Brown L, Clesi Giepert J, Black A, Farb H. Engagement Strategies to Advance Community-Centered Primary Care. J Public Health Manag Pract. 2017;23:S66-70. https://doi.org/10.1097/PHH.0000000000000662 